\title{
The Bay Leaves Active Compounds and Its Lipid Oxidative Inhibition Activity in Bulk Cooking Oil
}

\author{
DOI: $10.18196 /$ pt.v9i1.7143
}

\author{
Vritta Amroini Wahyudi*, Afifah Nuril Aini, Dian Puspita, Ayu Ramadhanni Kumala Dewi \\ Food Science and Technology Department, Agriculture and Animal Science Faculty, Muhammadiyah University of Malang, \\ Jl. Raya Tlogomas 246 Malang 65144, Indonesia \\ *Corresponding author, email:vritta@umm.ac.id
}

\begin{abstract}
Cooking oil is one of the basic human needs. Improving the quality of bulk cooking oil is necessary because it is related to economic reason. The bulk cooking oil have a lower price than brand package oil, of course. Based on these reasons, research is needed on the use of antioxidants to improve the quality of bulk cooking oil. This study aims to identify the phytochemicals of bay leaves extract through TOF profiling, analysis of iodine number and acid number of bay leaves extract against bulk cooking oil. TOF profiling was carried out to see whether bay leaves had chemical compounds that supported antioxidant activity which had an impact on the inhibition of fat oxidation. The research consisted of 4 stages: 1) extraction and fractionation of bay leaves, 2) TOF profiling of bay leaves extract, 3) application of bay leaves extract to bulk cooking oil, 4) analysis of iodine and acid numbers. Profiling TOF of the bay leaves extract showed 3 peaks : $\mathrm{C}_{5} \mathrm{H}_{13} \mathrm{NO}_{5}$ (cyclohexanol, galactose, and fructose derivatives) $\mathrm{C}_{11} \mathrm{H}_{14} \mathrm{O}_{5}$ (pyran and furan) and $\mathrm{C}_{11} \mathrm{H}_{19} \mathrm{NO}_{3}$ (morpholine derivate). According to SNI, the acid value maximum $0.6 \mathrm{mg} \mathrm{KOH/g}$. lodine value minimum is $45 \mathrm{glf} 100 \mathrm{~mL}$ (SNI 3741 : 2013). Based of this data standart, this study recommended use bay leaves extract in concentration 0.80\%. The addition of bay leaves extract as much as $0.80 \%$ showed an iodine number of $48.2 \mathrm{~g}$ I._.100 mL and an acid number of $0.34 \mathrm{mg} \mathrm{KOH/g}$ where the positive control TBHQ showed an iodine number of $48.7 \mathrm{~g} / . / 100 \mathrm{~mL}$ and an acid number of $0.19 \mathrm{mg} \mathrm{KOH} / \mathrm{g}$.
\end{abstract}

Keywords: Antioxidants, Bay leaves, Phytochemistry, Profiling TOF, Syzygium polyanthum

\section{ABSTRAK}

Minyak goreng merupakan salah satu kebutuhan pokok masyarakat. Peningkatan kualitas minyak goreng curah diperlukan karena terkait dengan alasan ekonomis. Minyak goreng curah tentunya memiliki harga yang lebih murah dari minyak kemasan merek. Berdasarkan alasan tersebut, diperlukan penelitian mengenai penggunakan antioksidan untuk meningkatkan kualitas minyak goreng curah. Penelitian ini bertujuan untuk mengidentifikasi fitokimia ekstrak daun salam melalui pembuatan profil TOF, analisis bilangan iod dan bilangan asam ekstrak daun salam terhadap minyak goreng curah. Profiling TOF dilakukan untuk melihat apakah daun salam memiliki senyawa kimia yang mendukung aktivitas antioksidan yang berdampak pada penghambatan oksidasi lemak. Penelitian ini terdiri dari 4 tahap yaitu, 1) ekstraksi dan fraksinasi daun salam, 2) profiling TOF ekstrak daun salam, 3) aplikasi ekstrak daun salam pada minyak goreng curah, 4) analisis bilangan iod dan asam. Profiling TOF ekstrak daun salam menunjukkan 3 puncak: $\mathrm{C}_{6} \mathrm{H}_{13} \mathrm{NO}_{5}$ (turunan sikloheksanol, galaktosa, dan fruktosa), $\mathrm{C}_{11} \mathrm{H}_{14} \mathrm{O}_{5}$ (pyran dan furan), dan $\mathrm{C}_{11} \mathrm{H}_{19} \mathrm{NO}_{3}$ (turunan morfolin). Menurut SNI, nilai asam maksimal 0,6 mg KOH/g. Bilangan iod minimal adalah $45 \mathrm{~g}$ I / 100 mL (SNI 3741: 2013). Berdasarkan standar data tersebut, penelitian ini merekomendasikan penggunaan ekstrak daun salam dengan konsentrasi 0,80\%. Penambahan ekstrak daun salam sebanyak 0,80\% menunjukkan bilangan yodium 48,2 و ا g /2/100 mL dan bilangan asam 0,34 mg KOH / g dimana kontrol positif TBHQ menunjukkan bilangan iodium 48,7 $\mathrm{g} / 2 / 100 \mathrm{~mL}$ dan bilangan asam 0,19 mg KOH/g.

Kata Kunci: Antioksidan, Daun salam, Fitokimia, Profiling TOF, Syzygium polyanthum

\section{INTRODUCTION}

Cooking oil is one of the basic human needs. ally, bulk palm oil is easily oxidized. Oxidation is There are two types of oil circulating in the community, namely packaged oil and bulk palm oil. Packaged oil means clear oil that goes through two filtering processes, while bulk palm oil means oil that only goes through one filtering process. Packaged oil is relatively more expensive than bulk palm oil. This is because packaged oil is packaged using an automatic machine while bulk palm oil is packaged manually. Because it is packaged manucaused by a reaction between free fatty acids and oxygen. Oxidation causes the fat to break down and gives the oil a rancid smell and taste. Improving the quality of bulk cooking oil is necessary because it is related to economic reason. The bulk cooking oil have a lower price than brand package oil, of course. Unfortunately, most consumers haven't known and aware that poor oil quality can cause various diseases such as increased levels of Low- 
Density Lipoprotein (LDL) in the blood which can cause coronary heart disease, cardiovascular disease, hypertension and cancer (Holmgren, 2012).

The shorter refining process of the bulk cooking oil caused it damaged easily than brand package oil. The damage process related with its lipid composition. Lipid is a triglyceride compound that consist of a glycerol and three fatty acids. The fatty acid has unsaturated bound which can react with UV or heat, it called lipid oxidation. Lipid oxidation can change aroma, colour, and develop the toxic compound of the food (Frankel, 2014, Berton-Carabin et al., 2014, Waraho et al., 2011). Therefore it is necessary to improve the quality by adding antioxidants to the oil. Antioxidants are compounds that can prevent, delay, and slow down the process of lipid oxidation (Ahmadi and Sila, 2020).

The antioxidant activity which related with inhibiting oxidation can be used as a simple solution to the use of cooking oil. So far, research on bulk cooking oil has been carried out to improve its quality through research on increasing the ion number and decreasing the acid number. The synthetic antioxidant such as butylated hydroxytoluene (BHT) and ethoxyquin (EQ) have been used to inhibit lipid oxidation in cooking oil. However, previous studies indicates that BHT and EQ can produce toxics and carcinogent compound in oil (Ding and Zou, 2012, Xu et al., 2014). So, it is essential to explore natural compound that have potential to inhibit lipid oxidation process.

Several plant extracts that have been used to improve the quality of bulk fried mint include red betel leaves (Widayani et al., 2018), carrot flour (Panagan, 2011), mangosteen peel (Basri, 2015), banana peel (Purwaningsih et al., 2019). Another natural ingredient that has the potential as an antioxidant is bay leaves (Syzygium polyanthum). Bay leaves are known to have high antioxidant activity (Wahyudi and Puspita, 2019). This is re- lated to some of the chemical content in it such as polyphenols (anthocyanin, flavonoid, flavone), isoprenoids (carotenoids, lycopene, monoterpene, xanthophyll), also another compound such as tocopherols (vitamin E), vitamin B6 (Ahmad, 2014, Rahman et al., 2014, Dewijanti et al., 2019). The antioxidant activity related with the potential lipid oxidation inhibition. The compound that have antioxidant activity means can inhibit the oxidation of substrates. The scavenging of reactive oxygen species is a possible action mechanism (Zamuz et al., 2018)

Bay leaves in Indonesia is known as a medicinal plant for health and food. This plant is also used by the community as a traditional medicine and flavoring cook (Harismah, 2017). Bay leaves (consist of aldehyde, terpenes, phenolic, alkane, diterpene alcohol, acyclic alkene, alkanes, bicyclic aromatic hydrocarbon, diol, fatty acid, fatty acid ester, lignan, methylated phenols (tocopherols), oxygenated terpenes, peroxides, phenolics, steroidal, saturated terpenoid alkane compunds (Abd Rahim et al., 2018, Widjajakusuma et al., 2019, Hamad et al., 2017). Bay leaves has pharmacological such as antiinflammatory, antibacterial, antinociceptive, antifungal, antulcer, hepatoprotective, antioxidant, antinociceptive (Dewijanti et al., 2020, Ismail and Ahmad, 2019, Rahman et al., 2014, Ramli et al., 2017).

Research on the antioxidant activity of bay leaves so far has limited at determining the value but has not been applied to other functions such as inhibiting oil damage. This study is expected to provide a new insight into the use of bay leaves which are commonly found with a more scientific function to improve the quality of bulk cooking oil. Consider with that, the purpose of this study are to identify the phytochemicals of bay leaves extract through TOF profiling, analysis of iodine number and acid number of bay leaves extract against bulk cooking oil. TOF profiling was carried out to see 
whether bay leaves had chemical compounds that supported antioxidant activity which had an impact on the inhibition of fat oxidation. The addition of bay leaves extract to bulk cooking oil is expected to increase the iodine number to show that the extract is able to maintain double bonds in bulk cooking oil triglycerides, as well as decrease the acid number to show that the extract can inhibit the formation of free fatty acids. The results of the study were then compared with SNI 3741: 2013, to provide recommendations for the concentration of bay leaves extract to improve the quality of bulk cooking oil.

\section{MATERIALS AND METHODS}

Bay leaves are obtained from Landungsari, Malang, East Java. The reagent was obtained from the Food Technology Chemistry Laboratory. The reagents used include technical TBHQ (Tertiary Butyl Hydro Quinone), n-hexane, technical ethyl acetate and technical methanol, Hanus reagent, technical carbon tetrachloride, sodium thiosulfate, starch, distilled water, potassium iodide, phenolphthalein, and potassium hydroxide.

\section{Extraction and Fractionation}

Syzygium polyanthum aerated until the accent smoothed until it becomes simplicial. Simplicial macerated with acetone for $3 \times 24$ hours. The maceration results are filtered to obtain filtrate and residues. The obtained filtrate was evaporated becomes crude extract. The crude extract of bay leaves was fractionated with a separating funnel using distillate solvent: n-hexane $\left(\mathrm{C}_{6} \mathrm{H}_{14}\right)$, ethyl acetate $\left(\mathrm{CH}_{3} \mathrm{COOC}_{2} \mathrm{H}_{5}\right)$, and methanol $\left(\mathrm{CH}_{3} \mathrm{OH}\right)$. The ethyl acetate fraction taken, and the solvent removed again using a rotary evaporator $\left(80^{\circ} \mathrm{C}\right.$, $30 \mathrm{rpm}$ ) until an ethyl acetate fraction extract obtained.

\section{Profiling TOF-MS}

Syzygium polyanthum extract was taken and then analyzed using TOF-MS (lc-ms-9030 Q-TOF Mass Spectrometer-Shimadzu Scientific). The extract was obtained from maceration for 3x24 hours (every 24 hours change the solvent) using technical acetone. Profiling take 3 highest peaks from the extract. Chromatography used a column $(1.8 \mu \mathrm{m}, 2.1 \times 150$ $\mathrm{mm}$, the column oven temperature was maintained at $35^{\circ} \mathrm{C}$, and the auto sampler temperature was maintained at $4^{\circ} \mathrm{C}$. The mobile phase was (A) $5 \mathrm{mM}$ tributylammonium acetate in air and (B) methanol. The linear gradient program starts with $98 \%$ of the total time is 35 minutes' cycle, with a flow rate of $300 \mu \mathrm{L} / \mathrm{min}$ and an injection volume of $5 \mu \mathrm{L}$ using full mode.

Application of Syzygium polyanthum Extract into Bulk Cooking Oil

Application of Syzygium polyanthum with addition the extract into bulk cooking oil (stirrer with temperature $180^{\circ} \mathrm{C}$ for 3 hours with $30 \mathrm{rpm}$ ). The extract was added into bulk oil with 6 concentrations: 0.1 (T1); 0.2 (T2); 0.4 (T3); 0.6 (T4); 0.8 (T5); and $1.0(\mathrm{~T} 6) \%(\mathrm{w} / \mathrm{v})$. The negative control is bulk cooking oil without any addition while the positive control is bulk cooking oil with TBHQ. TBHQ is a synthetic antioxidant which is approved by FDA (Food and Drug Administration) United States. TBHQ maximum allowed concentration according to FDA is $0.02 \mathrm{~g} / 100 \mathrm{~g}$ of oil $(0.20 \%)$ (Borsato et al., 2014).

\section{lodine Value Test (AOAC, 2005)}

Syzygium polyanthum $(0.1 \mathrm{~g})$ was added $20 \mathrm{~mL}$ technical carbon tetrachloride $\left(\mathrm{CCl}_{4}\right)$. The mixture was added Hanus reagen $(25 \mathrm{~mL})$. It shaked for a minute. The mixture kept in dark room $\left(\mathrm{T}=20^{\circ} \mathrm{C}\right.$, $\mathrm{t}=30$ minutes), and it was added $10 \mathrm{~mL}$ potassium iodide (KI) $15 \%$ and $100 \mathrm{~mL}$ aquades. It was shaked 
for 30 second, $30 \mathrm{rpm}$. The mixture was titrated with $0.1 \mathrm{~mol} / \mathrm{L}$ sodium thiosulfate $\left(\mathrm{Na}_{2} \mathrm{~S}_{2} \mathrm{O}_{4}\right)$ to obtain iodine value.

Iodine value $(\mathrm{g} \mathrm{I} / 2 / 100 \mathrm{~mL})=$ ((mL blank-mL sample )x $\mathrm{N}$ thiosulfat x $\mathrm{Mr}$ Iod $)$ sample mass (g)

\section{Acid Value Test (AOAC, 2005)}

The amount of free fatty acids was determined by the acid value. the sample was mixed with 50 $\mathrm{mL}$ of neutralized solvent. Then, the mixture was added phenolphthalein (pp indicator). After that, it was titrated with potassium hydroxide solution while constant swirling until the colour changes consistently.

Acid Value $(\mathrm{mg} \mathrm{KOH} / \mathrm{g})=$

$\underline{(\mathrm{mL} \mathrm{KOH} \times \mathrm{N} \mathrm{KOH} \times \mathrm{Mr} \mathrm{KOH})}$ sample mass (g)

\section{Analysis Method}

This research used a simple randomized design method with one factor. The concentrations added were six levels and one control (TBHQ as standard antioxidants), details are shown in Table 1 . The iodine and acid value were compared with SNI 01-3741-2002 (Indonesian National Standard for Cooking Oil).

Table 1. The Treatment of Adding Bay Leaves Extract to Bulk Cooking Oil

\begin{tabular}{lcc}
\hline Sample & Bay Leaves Extract (\%w/v) & TBHQ (\%w/v) \\
\hline Control (T0) & - & - \\
Treatment 1 (T1) & 0.10 & - \\
Treatment 2 (T2) & 0.20 & - \\
Treatment 3 (T3) & 0.40 & - \\
Treatment 4 (T4) & 0.60 & - \\
Treatment 5 (T5) & 0.80 & - \\
Treatment 6 (T6) & 1.00 & - \\
Treatment 7 (T7) & - & $0.20 \%$ \\
\hline
\end{tabular}

\section{RESULTS AND DISCUSSION}

Profiling TOF of Bay Leaves Extract

In this study, profiling takes 3 higher peaks from the extract to find out what compounds have a role in the activity. The results shown 3 higher peaks on Retention Time (RT): 1.26, 3.38, and 5.40. Retention time measured the time of the compound to pass the chromatography column. Each retention time shown specific compound with certain molecule mass $(\mathrm{m} / \mathrm{z})$. In this study, $\mathrm{m} / \mathrm{z}$ data was interpretation with TOF-MS library and addition with database of natural product (DNP).

Peak 1 (Figure 1) has retention time on 1.26 with $\mathrm{m} / \mathrm{z}$ 180.0866. The molecule formula from the profiling TOF is $\mathrm{C}_{6} \mathrm{H}_{13} \mathrm{NO}_{5}$ refers to 4 possible compounds (Table 2). It can be seen in Table 1, peak 1 (RT 1.26) with the formula $\mathrm{C}_{6} \mathrm{H}_{13} \mathrm{NO}_{5}$ with a molecular mass of $180.0866 \mathrm{~g} / \mathrm{mol}$, referring to 4 predictions of compounds from cyclohesanol derivatives with amine groups.

Compound 6-amino-1,2,3,4,5-cyclohexanepentol, 1-amino-1-deoxyfructose, galactosamine (2-amino-2-deoxygalactose), and 5-amino-5-deoxygalactose have similar pattern structure, which is all that compound have hydroxyl functional group. Compound 6-amino-1,2,3,4,5-cyclohexanepentol is a cyclohexanol group which have 5 hydroxyls functional group. Compound 1-amino-1-deoxyfructose is fructose which lost one hydroxyl and replaces with an amino functional group. Compound 1-amino-1-deoxyfructose was known as antidiabetic and antiaging activity. Compound galactosamine (2-amino-2-deoxygalactose) and 5-amino-5-deoxygalactose are deoxy galactose derivative. The hydroxyl groups have a high electronegative so that if a compound has many hydroxyl groups, the compound will have potential as an antioxidant (Mossine and Mawhinney, 2010).

Peak 2 (Figure 2) have retention time on 3.38 with $\mathrm{m} / \mathrm{z}$ 227.0914. The molecule formula from 


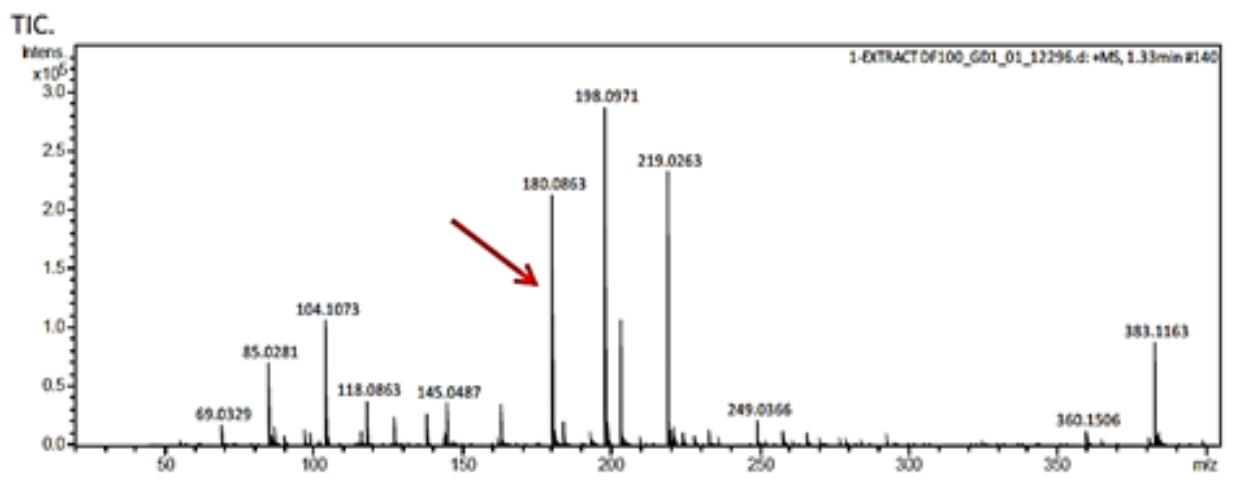

Figure 1. Profiling TOF Result of Bay Leaves Extract : Peak 1 (RT = 1.26)

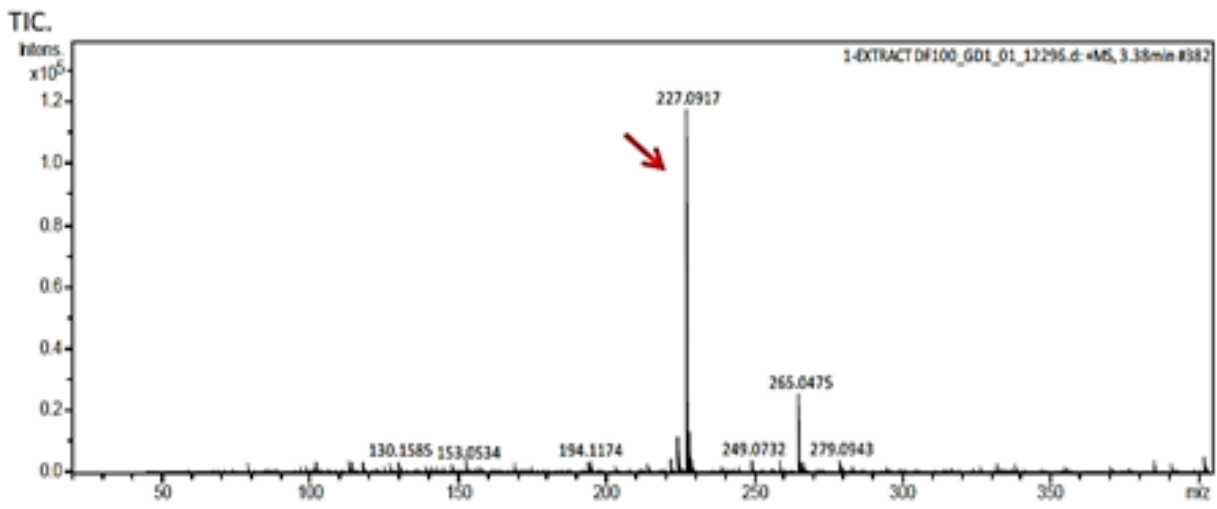

Figure 2. Profiling TOF Result of Bay Leaves Extract : Peak 2 (RT = 3.38)

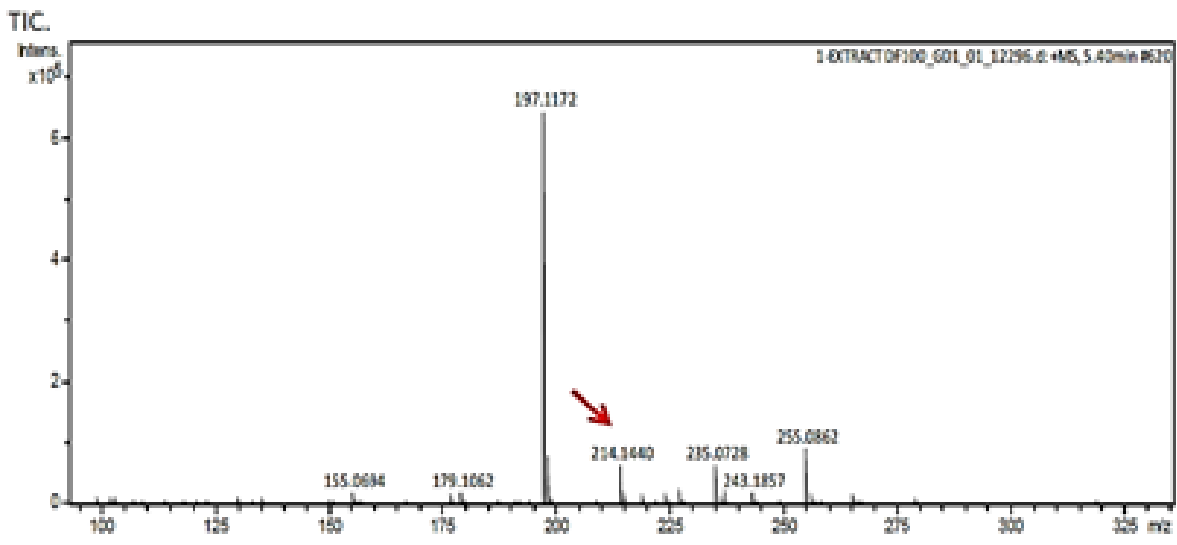

Figure 3. Profiling TOF Result of Bay Leaves Extract : Peak $3(R T=5.40)$

the profiling TOF is $\mathrm{C}_{11} \mathrm{H}_{14} \mathrm{O}_{5}$ refers to 19 possible oxidation. It can reduce the thrombotic tendency. compounds (Table 2). Peak 2 refer to pyran or furan The pyran and furan structure can inhibit lipid oxicompounds. Pyran and furan formed in flavonoid dation from meat and oil extract from fish (Angaji biosynthesis pathway which proved have potential et al., 2012). So, it annalitically proofed that bay as antioxidant or lipid oxidation inhibition. leaves has potential as oxidation inhibitor because

Pyran ring can be opened as a chalcones struc- it consist of pyran and furan structure. ture and recycled into a furan ring as an aurones. It Peak 3 (Figure 3) has retention time on 5.40 has similar potential with flavonoid group that can with $\mathrm{m} / \mathrm{z}$ 214.1438. The molecule formula from quench active oxygen, also can inhibit low density the profiling TOF is $\mathrm{C}_{11} \mathrm{H}_{19} \mathrm{NO}_{3}$ refers to 2 possible 
Table 2. Profiling TOF-MS Result of Bay Leaves Extract

\begin{tabular}{|c|c|c|c|c|}
\hline Peak Number & RT & Molecule Formula & $\mathrm{m} / \mathrm{z}$ & Name Prediction \\
\hline \multirow[t]{5}{*}{1} & \multirow[t]{5}{*}{1.26} & \multirow{5}{*}{$\mathrm{C}_{6} \mathrm{H}_{13} \mathrm{NO}_{5}$} & \multirow[t]{5}{*}{180.0866} & 6-Amino-1,2,3,4,5-cyclohexanepentol \\
\hline & & & & 1-Amino-1-deoxyfructose \\
\hline & & & & Galactosamine \\
\hline & & & & (2-Amino-2-deoxygalactose) \\
\hline & & & & 5-Amino-5-deoxygalactose \\
\hline \multirow[t]{19}{*}{2} & \multirow[t]{8}{*}{3.38} & \multirow[t]{8}{*}{$\mathrm{C}_{11} \mathrm{H}_{14} \mathrm{O}_{5}$} & \multirow[t]{8}{*}{227.914} & $\begin{array}{l}\text { (5S,6R)-5-Hydroxy-6-methyl-3-[(2S,3S)-3-methyl-2-oxiranyl]-5,6-dihydro- } \\
2 \mathrm{H} \text {-pyran-2-one }\end{array}$ \\
\hline & & & & 2-(2-Carboxyethyl)-5-propyl-3-furoic acid \\
\hline & & & & $\begin{array}{l}\text { Chaetoglocin A/ 6-[(2E)-1-hydroxybut-2-en 2-yl]-5-(hydroxymethyl)-4- } \\
\text { methoxy-2H-pyran-2-one }\end{array}$ \\
\hline & & & & $\begin{array}{l}\text { Chlamydosporol/ (7S,8S)-7-Hydroxy-4-methoxy-7,8-dimethyl-7,8-dihydro- } \\
2 \mathrm{H}, 5 \mathrm{H} \text {-pyrano[4,3-b]pyran-2-one }\end{array}$ \\
\hline & & & & $\begin{array}{l}\text { Dunnisinin/ Methyl (2aS,4aS,7bS)-2a-hydroxy-2a,4a,5,6,7a,7b-hexahydro- } \\
2 \mathrm{H}-1,7 \text {-dioxacyclopenta[cd] indene-5-carboxylate }\end{array}$ \\
\hline & & & & $\begin{array}{l}\text { Isochlamydosporol/ }(5 \mathrm{R}, 7 \mathrm{~S}, 8 \mathrm{~S})-5 \text {-Hydroxy-4-methoxy-7,8-dimethyl-7,8- } \\
\text { dihydro-2H,5H-pyrano[4,3-b]pyran-2-on }\end{array}$ \\
\hline & & & & $\begin{array}{l}\text { Isochlamydosporol/ }(5 \mathrm{R}, 7 \mathrm{~S}, 8 \mathrm{~S})-5 \text {-Hydroxy-4-methoxy-7,8-dimethyl-7,8- } \\
\text { dihydro-2H,5H-pyrano[4,3-b]pyran-2-on }\end{array}$ \\
\hline & & & & 1-(7-Methoxy-1,3-benzodioxol-5-yl)-1,2-propanediol \\
\hline & & \multirow[t]{11}{*}{$\mathrm{C}_{11} \mathrm{H}_{14} \mathrm{O}_{5}$} & & 1-(3-Methoxy-4,5-methylenedioxyphenyl)-1,2-propanediol \\
\hline & & & & $\begin{array}{l}\text { Eutypellin B/ (3E,4S,5R)-4-Hydroxy-3-[(2E)-4-hydroxy-2-buten-1-ylidene]-5- } \\
\text { [(1E)-3-hydroxy-1-propen-1-yl]dihydro-2(3H)-furanone }\end{array}$ \\
\hline & & & & 4-Hydroxy-3,5-dimethoxy-4-(2-oxopropyl)-2,5-cyclohexadien-1-one \\
\hline & & & & $\begin{array}{l}\text { Olenoside A/ Methyl (4aS,8R,8aR)-8-methyl-3-oxo-4,4a,8,8a-tetrahydro- } \\
\text { 1H,3H-pyrano[3,4-c]pyran-5-carboxylate }\end{array}$ \\
\hline & & & & $\begin{array}{l}\text { Rosigenin/ (3S,4S,6R,10S)-4,6-Dihydroxy-3,10-dimethyl-2-oxaspiro[4.5] } \\
\text { dec-8-ene-1,7-dione }\end{array}$ \\
\hline & & & & Sarracenin/2,5-Methano-4H,5H-pyrano[2,3-d]-1,3-dioxin-6-carboxylic acid \\
\hline & & & & $\begin{array}{l}\text { Speciosin A/ (5S)-1-(3-Buten-1-yn-1-yl)-5-hydroxy-7-oxabicyclo[4.1.0] } \\
\text { hept-3-en-2-one }\end{array}$ \\
\hline & & & & $\begin{array}{l}\text { Speciosin A/ (1R,5S,6R)-1-(3-Buten-1-yn-1-yl)-5-hydroxy-7-oxabicyclo[4.1.0] } \\
\text { hept-3-en-2-one }\end{array}$ \\
\hline & & & & $\begin{array}{l}\text { (3S,7S,7aR)-3,7,7a-Trihydroxy-4-[(1E)-1-propen-1-yl]-3,6,7,7a- } \\
\text { tetrahydrocyclopenta[c]pyran-5(1H)-one }\end{array}$ \\
\hline & & & & Verbenalol \\
\hline & & & & Xialenon C \\
\hline \multirow[t]{2}{*}{3} & \multirow[t]{2}{*}{5.40} & \multirow{2}{*}{$\mathrm{C}_{11} \mathrm{H}_{19} \mathrm{NO}_{3}$} & \multirow[t]{2}{*}{214.1438} & 3,6-Diisopropyl-4-methyl-2,5-morpholinedione \\
\hline & & & & 3,6-Diisopropyl-4-methyl-2,5-morpholinedione \\
\hline
\end{tabular}

compounds; there are 3,6-diisopropyl-4-methyl-2,5- morpholinedione are morpholinedione group morpholinedione and 3,6-diisopropyl-4-methyl-2,5- which one pathway with depsipeptides. Depsipepmorpholinedione. Previous research aims that tide is a compound which have amide and ester morpholine compound have antibacterial and group from condensation reaction of protein. anticancer activity (AlTamiemi et al., 2015). Previous study mentions that morpholinedione

Compound 3,6-diisopropyl-4-methyl-2,5-mor- have antioxidant activity and it has been tested pholinedione and 3,6-diisopropyl-4-methyl-2,5- in vitro. The structure of depsipeptide that react 
further to be cyclodepsipeptides proven reduce oxidation activity in DPPH-radical scavenging capacity test. The activity relatable with hydrogen atom abstraction from the activated $\mathrm{C}-\mathrm{H}$ group at the morpholinedione ring possision (Jovanovic et al., 2012).

\section{lodine and Acid Value Test}

In this study, analysis of iodine number and acid number was carried out to determine the inhibition activity of used bulk cooking oil damage. The bulk cooking oil without addition of bay leaves extract and TBHQ showed an iodine number of $42.9 \mathrm{~g}$ $\mathrm{I}_{2} / 100 \mathrm{~mL}$ and an acid number of $0.42 \mathrm{mg} \mathrm{KOH} / \mathrm{g}$ (T0). The addition of bay leaves extract to bulk cooking oil showed iodine numbers of 43.9 (T1), 43.0 (T2), 42.6 (T3), 43.8 (T4), 48.2 (T5), and 47, 7 (T6) $\mathrm{g} \mathrm{I}_{2} / 100 \mathrm{~mL}$ (Table 3). The iodine numbers $\mathrm{T} 5$ and $\mathrm{T} 6$ are close to the iodine numbers from the addition of TBHQ. The TBHQ iodine number for bulk cooking oil was $48.7 \mathrm{~g} \mathrm{I}_{2} / 100 \mathrm{~mL}$ (T7). Based on the results of these iodine numbers, it appears that the bay leaves extract with an additional amount of $0.80-1.00 \%(\mathrm{w} / \mathrm{v})$ can have an inhibitory activity close to TBHQ (0.20\%).

Table 3. The Result of lodine and Acid Value Analysis

\begin{tabular}{ccc}
\hline Treatment & $\begin{array}{c}\text { lodine Value } \\
\left(\mathrm{g} \mathrm{I}_{2} / 100 \mathrm{~mL}\right)\end{array}$ & $\begin{array}{c}\text { Acid Value } \\
(\mathrm{mg} \mathrm{KOH} / \mathrm{g})\end{array}$ \\
\hline T0 & 42.9 & 0.42 \\
$\mathrm{~T} 1$ & 43.9 & 0.39 \\
$\mathrm{~T} 2$ & 43.0 & 0.44 \\
$\mathrm{~T} 3$ & 42.6 & 0.39 \\
$\mathrm{~T} 4$ & 43.8 & 0.34 \\
$\mathrm{~T} 5$ & 48.2 & 0.34 \\
$\mathrm{~T} 6$ & 47.7 & 0.34 \\
$\mathrm{~T} 7$ & 48.7 & 0.19 \\
\hline
\end{tabular}

Iodine value reflects unsaturation of fatty acids making up oil and fat. Unsaturated fatty acids can bind iodine and form a compound saturated. The number of iodine tied shows many double bonds.
The more iodine numbers are measured, the more acid content there is unsaturated fats in oils, it means increased the quality of that cooking oil (Harini et al., 2019). In Indonesia, there is a standard national of iodine value cooking oil. Iodine value minimum is $45 \mathrm{~g} \mathrm{I}_{2} / 100 \mathrm{~mL}$ (SNI 3741 : 2013). Bulk cooking oil (without addition anything) have an iodine value of $4.9 \mathrm{~g} \mathrm{I}_{2} / 100 / \mathrm{mL}$ which does not make suitable with SNI. Addition bay leaves extract in $0.8 \%$, and $1.0 \%$ increased the iodine value, it is revealed the improvement of quality of bulk oil.

Another parameter to determine of the lipid potential as oxidation inhibitor is acid value. The acid values indicated free fatty acid (FFA) which release from triglyceride structure. The acid number in bulk oil without the addition of bay leaves extract and TBHQ was $0.42 \mathrm{mg} \mathrm{KOH} / \mathrm{g}$ (Table 1). The addition of bay leaves extract shows a decrease in the fatty acid number, this indicates that the bay leaves extract can inhibit the formation of free fatty acids in bulk cooking oil. The acid numbers in bulk cooking oil added with bay leaves extract are 0.39 (T1), 0.44 (T2), 0.39 (T3), 0.34 (T4), 0.34 (T5), and 0.34 (T6) $\mathrm{mg} \mathrm{KOH} / \mathrm{g}$. The value of the acid number in the addition of TBHQ is $0.19 \mathrm{mg} \mathrm{KOH}$ / $\mathrm{g}$ (Table 1). The result showed that it is suitable with SNI of cooking oil (acid value max 0.6). The high number of acids means that it is equivalent to high levels of free fatty acids. The triglycerides contained in many have been broken down into free fatty acids while in hydrolysis process (Harini et al., 2019). This step occurs in the process of heating oil at high temperatures and repeatedly.

From the iodine and acid value test (Tabel 3), This study shows that the bay leaves extract has an iodine number that is close to the TBHQ iodine number, while the acid number of the bay leaves extract is still lower than the TBHQ acid number. These results indicate a rational hypothesis that the performance mechanism of the bay leaves extract 


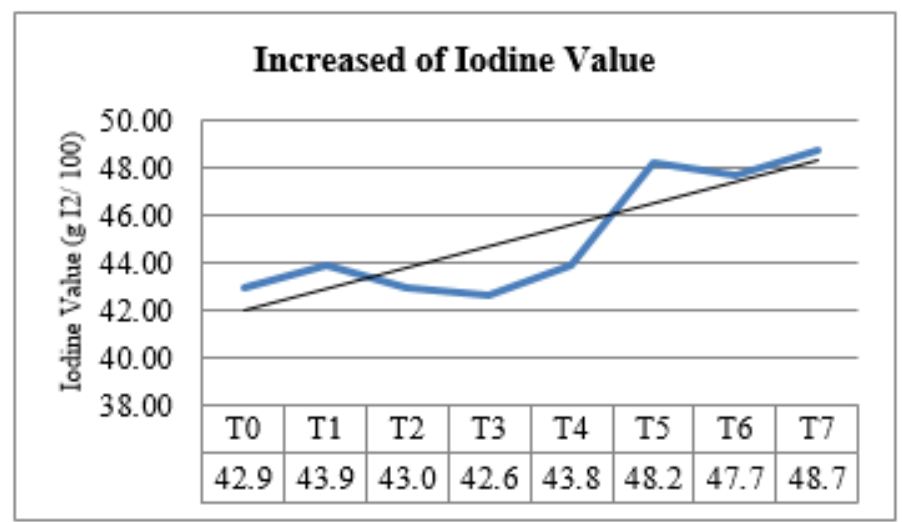

TO = bulk oil

$\mathrm{Tl}=$ bulk oil + extract $(0.10 \%)$

$\mathrm{T} 2=$ bulk oil + extract $(0.20 \%)$

T3 $=$ bulk oil + extract $(0.40 \%)$

T4 $=$ bulk oil + extract $(0.60 \%)$

T5 $=$ bulk oil + extract $(0.80 \%)$

T6 $=$ bulk oil + extract $(1.00 \%)$

T7 = bulk oil + TBHQ $(0.20 \%)$

Figure 4. The lodine Value of Bulk Cooking Oil which added extract and TBQ (standard)

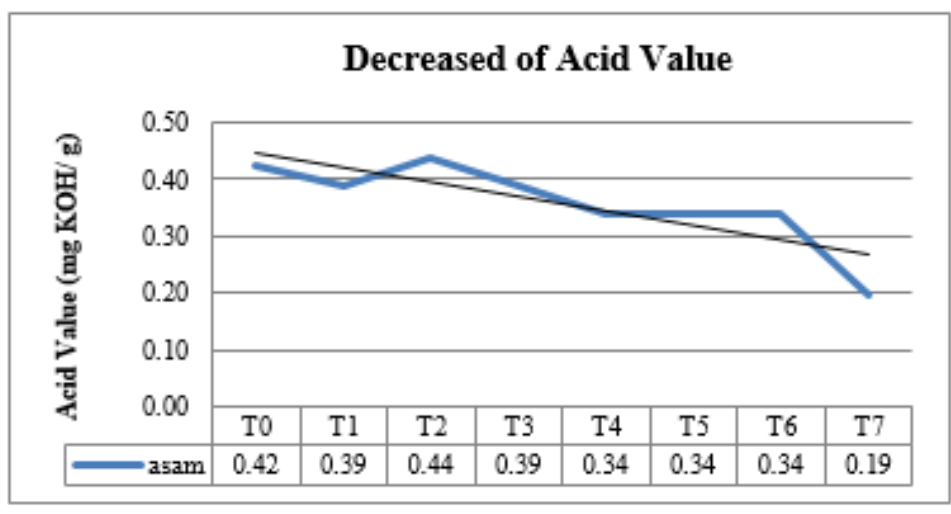

$\mathrm{T} 0=$ bulk oil

$\mathrm{Tl}=$ bulk oil + extract $(0,10 \%)$

$\mathrm{T} 2=$ bulk oil + extract $(0,20 \%)$

T3 $=$ bulk oil + extract $(0,40 \%)$

T4 $=$ bulk oil + extract $(0,60 \%)$

T5 $=$ bulk oil + extract $(0,80 \%)$

T6 $=$ bulk oil + extract $(1,00 \%)$

$\mathrm{T} 7=$ bulk oil + TBHQ $(0,20 \%)$

Figure 5. The Acid Value of Bulk Cooking Oil which added extract and TBQ (standard)

is more effective in maintaining the triglyceride double bonds of bulk cooking oil compared to maintaining the bonds of triglyceride fatty acids. The ability to maintain triglyceride double bonds is related to the high antioxidant activity of bay leaves. Bay leaves extract is known to have higher antioxidant activity than quercetin (Har and Intan, 2012).

The Best Treatment for Application in Bulk Cooking Oil

As explained earlier, the use of bay leaves extract in bulk oil is a good step to improve its quality in terms of the addition of antioxidants. The use of cooking oil in Indonesia is certainly through SNI 01-3741-2002. According to SNI, the acid value maximum $0.6 \mathrm{mg} \mathrm{KOH} / \mathrm{g}$. Iodine value minimum is $45 \mathrm{~g} \mathrm{I}_{2} / 100 \mathrm{~mL}$ (SNI $3741: 2013$ ). Based of this data standart, this study recommended use bay leaves extract in concentration $0.80 \%$

\section{CONCLUSION}

The results showed the possibility of active compounds in bay leaves extract are cyclohexanol, galactose, and fructose derivative $\left(\mathrm{C}_{6} \mathrm{H}_{13} \mathrm{NO}_{5}\right)$, pyran and furan group $\left(\mathrm{C}_{11} \mathrm{H}_{14} \mathrm{O}_{5}\right)$, and morpholine derivate $\left(\mathrm{C}_{11} \mathrm{H}_{19} \mathrm{NO}_{3}\right)$. Bay leaf extract has been shown to improve the quality of bulk cooking oil through inhibition of fat oxidation from increasing iodine numbers and decreasing acid numbers. The bulk cooking oil without addition of bay leaves extract and TBHQ showed an iodine number of 42.9 $\mathrm{g} \mathrm{I}_{2} / 100 \mathrm{~mL}$ (control TBHQ $=48.7 \mathrm{~g} \mathrm{I}_{2} / 100 \mathrm{~mL}$ ) and an acid number of $0.42 \mathrm{mg} \mathrm{KOH} / \mathrm{g}$ (control $\mathrm{TBHQ}=0.19 \mathrm{mg} \mathrm{KOH} / \mathrm{g}$ ). According to SNI, the acid value maximum $0.6 \mathrm{mg} \mathrm{KOH} / \mathrm{g}$. Iodine value minimum is $45 \mathrm{~g} \mathrm{I}_{2} / 100 \mathrm{~mL}$ (SNI 3741 : 2013). Based of this data standart, this study recommended use bay leaves extract in concentration $0.80 \%$. 


\section{REFERENCES}

Abd Rahim, E. N. A., Ismail, A., Omar, M. N., Rahmat, U. N. \& Ahmad, W. A. N. W. 2018. GC-MS analysis of phytochemical compounds in Syzygium polyanthum leaves extracted using ultrasoundassisted method. Pharmacognosy Journal, 10. doi: $\underline{10.5530 /}$ pj.2018.1.20

Ahmad, N. 2014. Chemical composition, antioxidant and antibacterial activity of essential oil from leaf of Syzygium polyanthum (wight) walp. Thesis submitted in fulfillment of the requirements for the award of the ....

Ahmadi, K. \& Sila, M. D. 2020. Pengaruh Penambahan Antioksidan Dalam Mencegah Proses Oksidasi Minyak Sawit Curah. Fakultas Pertanian Universitas Tribhuwana Tunggadewi.

Altamiemi, E. O., Khammas, S. J. \& Alkaissi, S. S. 2015. Synthesis, Characterization and Study the Biological Activity of New Morpholine Derivative. Baghdad Science Journal, 12. doi: 10.21123/ bsj.12.4.761-773

Angaji, S. A., Mousavi, S. F. \& Babapour, E. 2012. Antioxidants: A few key points. Annals of Biological Research, 3 3968-3977.

Basri, L. M. 2015. Pengaruh Penambahan Ekstrak Kulit Manggis terhadap Ketahanan Oksidasi Minyak Goreng Curah. Jurnal Iptek, 1 34-38. doi: 10.31543/jii.v1i1.59

Berton-Carabin, C. C., Ropers, M. H. \& Genot, C. 2014. Lipid oxidation in oil-in-water emulsions: Involvement of the interfacial layer. Comprehensive Reviews in Food Science and Food Safety, 13 945-977. doi: 10.1111/1541-4337.12097

Borsato, D., De Moraes Cini, J. R., Da Silva, H. C., Coppo, R. L., Angilelli, K. G., Moreira, I. \& Maia, E. C. R. 2014. Oxidation kinetics of biodiesel from soybean mixed with synthetic antioxidants BHA, BHT and TBHQ: Determination of activation energy. Fuel processing technology, 127 111-116. doi: 10.1016/j. fuproc.2014.05.033

Dewijanti, I., Mangunwardoyo, W., Artanti, N. \& Hanafi, M. Bioactivities of Salam leaf (Syzygium polyanthum (Wight) Walp). AIP Conference Proceedings, 2019. AIP Publishing LLC, 020072. doi: $10.1063 / 1.5132499$

Dewijanti, I., Mangunwardoyo, W., Dwiranti, A., Hanafi, M. \& Artanti, N. 2020. Effects of the various source areas of Indonesian bay leaves (Syzygium polyanthum) on chemical content and antidiabetic activity. Biodiversitas Journal of Biological Diversity, 21. doi: $10.13057 /$ biodiv/d210345

Ding, M. \& Zou, J. 2012. Rapid micropreparation procedure for the gas chromatographic-mass spectrometric determination of BHT, BHA and TBHQ in edible oils. Food chemistry, 131 10511055. doi: 10.1016/j.foodchem.2011.09.100

Frankel, E. N. 2014. Lipid oxidation, Elsevier.

Hamad, A., Mahardika, M., Yuliani, I. \& Hartanti, D. 2017. Chemical constituents and antimicrobial activities of essential oils of Syzygium polyanthum and Syzygium aromaticum. Rasayan J. Chem, 10 564-569.

Har, L. \& Intan, S. I. 2012. Antioxidant activity, total phenolics and total flavonoids of Syzygium polyanthum (Wight) Walp leaves. International Journal of Medicinal and Aromatic Plants, 2 219-228.

Harini, N., Renita M. S. \& Wahyudi, V. A. 2019. Analisa Pangan, Zifatama Jawara.

Harismah, K. 2017. Pemanfaatan Daun Salam (Eugenia Polyantha) Sebagai Obat Herbal Dan Rempah Penyedap Makanan. Warta Lpm, 19 110-118. doi: 10.23917/warta.v19i2.2742

Holmgren, D. 2012. Future scenarios: How communities can adapt to peak oil and climate change, Chelsea Green Publishing.
Ismail, A. \& Ahmad, W. A. N. W. 2019. Syzygium polyanthum (Wight) Walp: a potential phytomedicine. Pharmacognosy Journal, 11. doi: 10.5530/pj.2019.11.67

Jovanovic, T., Kazama, A., Bachevalier, J. \& Davis, M. 2012. Impaired safety signal learning may be a biomarker of PTSD. Neuropharmacology, 62 695-704. doi: 10.1016/j.neuropharm.2011.02.023

Mossine, V. V. \& Mawhinney, T. P. 2010. 1-Amino-1-deoxy-Dfructose ("fructosamine") and its derivatives. Advances in carbohydrate chemistry and biochemistry, 64 291-402. doi: 10.1016/S0065-2318(10)64006-1

Panagan, A. T. 2011. Pengaruh penambahan tepung wortel (daucus carrota I.) terhadap bilangan peroksida dan asam lemak bebas pada minyak goreng curah. Jurnal Penelitian Sains, 14.

Purwaningsih, D. Y., Zuchrilah, D. R. \& Nurmala, I. 2019. Peningkatkan Mutu Minyak Goreng Curah dengan Penambahan Ekstrak Kulit Pisang Raja Sebagai Antioksidan Alami. Reka Buana: Jurnal IImiah Teknik Sipil dan Teknik Kimia, 4 22-29. doi: 10.33366/ rekabuana.v4i1.1058

Rahman, N., Bahriul, P. \& Diah, A. W. M. 2014. Uji aktivitas antioksidan ekstrak daun salam (Syzygium Polyanthum) dengan menggunanakan 1, 1-Difenil-2-Pikrilhidrazil. Jurnal Akademika Kimia, 3 143-149.

Ramli, S., Radu, S., Shaari, K. \& Rukayadi, Y. 2017. Antibacterial activity of ethanolic extract of Syzygium polyanthum L.(Salam) leaves against foodborne pathogens and application as food sanitizer. BioMed research international, 2017. doi: 10.1155/2017/9024246

Wahyudi, V. A. A., Afifah, N., Puspita, D. D., \& Kumala, A. R. 2019. Uji Aktivitas Antioksidan Fraksi Etil Asetat Daun Salam (Syzygium polyanthum) dan Uji Bilangan Peroksida-nya Terhadap Minyak Goreng Curah. Food Technology and Halal Science Journal, 55-63. doi: 10.22219/fths.v1i1.7547

Waraho, T., Mcclements, D. J. \& Decker, E. A. 2011. Mechanisms of lipid oxidation in food dispersions. Trends in Food Science \& Technology, 22 3-13. doi: 10.1016/j.tifs.2010.11.003

Widayani, A., Cahyono, E. \& Harjono, H. 2018. Isolasi dan Uji Antioksidan Minyak Atsiri Daun Sirih Merah (Piper crocatum Ruiz \& Pav.) pada Minyak Goreng Curah. Indonesian Journal of Chemical Science, 7 214-220.

Widjajakusuma, E. C., Jonosewojo, A., Hendriati, L., Wijaya, S., Surjadhana, A., Sastrowardoyo, W., Monita, N., Muna, N. M., Fajarwati, R. P. \& Ervina, M. 2019. Phytochemical screening and preliminary clinical trials of the aqueous extract mixture of Andrographis paniculata (Burm. f.) Wall. ex Nees and Syzygium polyanthum (Wight.) Walp leaves in metformin treated patients with type 2 diabetes. Phytomedicine, 55 137-147. doi: 10.1016/j.phymed.2018.07.002

Xu, S., Chen, F., Deng, M. \& Sui, Y. 2014. Simple simultaneous determination of butylated hydroquinone (TBHQ) and butylated hydroxyanisole (BHA) antioxidants in oil using high-performance liquid chromatography with chemiluminescence detection. Luminescence, 29 1027-1032. doi: 10.1002/bio.2654

Zamuz, S., López-Pedrouso, M., Barba, F. J., Lorenzo, J. M., Domínguez, H. \& Franco, D. 2018. Application of hull, bur and leaf chestnut extracts on the shelf-life of beef patties stored under MAP: Evaluation of their impact on physicochemical properties, lipid oxidation, antioxidant, and antimicrobial potential. Food Research International, 112 263-273. doi: 10.1016/j. foodres.2018.06.053 


\section{APPENDIX}

Appendix 1. The Base Structure of the Compound from TOF Proflling In Bay Leaves<smiles>C1=CC2CCCOC=C1C2</smiles>

Pyran Structure<smiles>c1ccoc1</smiles>

Furan Structure

Appendix 2. Compound Structure from the TOF Proflling In Bay Leaves<smiles>N[C@H]1C(O)[C@H](O)[C@@H](O)[C@H](O)[C@@H]1O</smiles>

6-Amino-1,2,3,4,5-cyclohexanepentol<smiles>N[C@H]1C(O)O[C@H](CO)[C@@H](O)[C@H]1O</smiles>

Galactosamine (2-amino-2-deoxygalactose)<smiles>C[C@@H]1O[C@H]1C1=C[C@H](O)[C@@H](C)OC1=O</smiles>

(5S,6R)-5-Hydroxy-6-methyl-3[(2S,3S)-3-methyl-2-oxiranyl]5,6-dihydro-2H-pyran-2-one

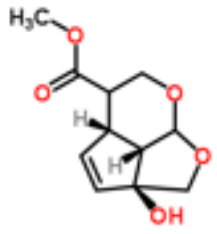

Dunnisinin/Methyl (2aS,4aS, 7bS)-2a-hydroxy$2 \mathrm{a}, 4 \mathrm{a}, 5,6,7 \mathrm{a}, 7 \mathrm{~b}$-hexahydro$2 \mathrm{H}-1,7-$

dioxacyclopenta[cd]indene-5carboxylate<smiles>CCCc1cc(C(=O)O)c(CCC(=O)O)o1</smiles>

2-(2-Carboxyethyl)-5-propyl-3furoic acid<smiles>COc1cc(=O)oc2c1[C@H](O)O[C@H](C)[C@H]2C</smiles>

Isochlamydosporol/ (5R,7S,8S)-5-Hydroxy-4methoxy-7,8-dimethyl-7,8dihydro-2H,5H-pyrano[4,3b]pyran-2-on<smiles>NCC1(O)OC[C@@H](O)[C@H](O)[C@H]1O</smiles>

1-Amino-1-deoxyfructose<smiles>N[C@@H](CO)[C@@H](O)C(O)(O)[C@H](O)C=O</smiles>

5-Amino-5-deoxygalactose<smiles>C/C=C(\CO)c1oc(=O)cc(OC)c1CO</smiles>

Chaetoglocin A/ 6-[(2E)-1hydroxybut-2-en-2-yl]-5(hydroxymethyl)-4-methoxy$2 \mathrm{H}$-pyran-2-one<smiles>COc1cc(=O)oc2c1[C@H](O)[C@H](C)O[C@H]2C</smiles>

Isochlamydosporol/ (5R,7S,8S)-5-Hydroxy-4methoxy-7,8-dimethyl7,8-dihydro- $2 \mathrm{H}, 5 \mathrm{H}$ pyrano[4,3-b]pyran-2-on<smiles>COc1cc(=O)oc2c1CO[C@](C)(O)[C@H]2C</smiles>

Chlamydosporol (7S,8S)-7Hydroxy-4-methoxy-7,8dimethyl-7,8-dihydro- $2 \mathrm{H}, 5 \mathrm{H}$ pyrano[4,3-pyran-2-one<smiles>COc1cc(C(O)C(C)O)cc2c1OCO2</smiles>

1-(7-Methoxy-1,3benzodioxol-5-yl)-1,2propanediol 
<smiles>COc1cc(C(O)C2CC2)cc2c1OCO2</smiles>

1-(3-Methoxy-4,5methylenedioxyphenyl)-1,2propanediol

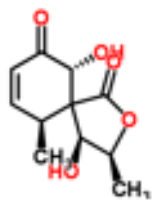

Rosigenin/ (3S,4S,6R,10S)4,6-Dihydroxy-3,10-

dimethyl-2-oxaspiro[4.5] dec8-ene-1,7-dione

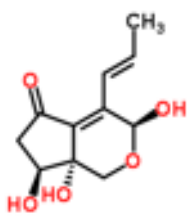

(3S,7S,7aR)-3,7,7a-

Trihydroxy-4-[(1E)-1-propen1-yl]-3,6,7,7a-

tetrahydrocyclopenta[c]pyran5(1H)-one<smiles>O=C1O[C@H](/C=C/CO)C(O)/C1=C\C=C\CO</smiles>

Eutypellin B/ (3E,4S,5R)-4Hydroxy-3-[(2E)-4-hydroxy2-buten-1-ylidene]-5-[(1E)-3hydroxy-1-propen-1yl]dihydro-2(3H)-furanone

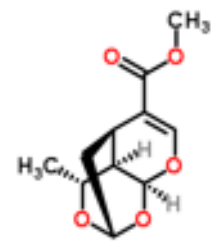

Sarracenin/ 2,5-Methano4H,5H-pyrano[2,3-d]-1,3dioxin-6-carboxylic acid

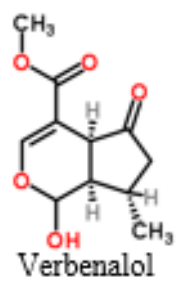<smiles>CC(C)=O</smiles>

II

4-Hydroxy-3,5dimethoxy-4-(2oxopropyl)-2,5cyclohexadien-1-one<smiles>C=CC#CC12OC1C(=O)C=C[C@@H]2O</smiles>

Speciosin A/ (5S)-1-(3Buten-1-yn-1-yl)-5hydroxy-7oxabicyclo[4-1.0]hept-3en-2-one<smiles>COC(C)=O</smiles><smiles>C=CCC1=C(O)C(=O)[C@]2(O)CC[C@H](O)[C@]12O</smiles>

Xialenon C
Olenoside A/ Methyl (4aS,8R,8aR)-8-methyl-3oxo-4,4a,8,8a-tetrahydro$1 \mathrm{H}, 3 \mathrm{H}$-pyrano[3,4c]pyran-5-carboxylate<smiles>C=CC#CC12O[C@H]1C(=O)C=C[C@H]2O</smiles>

Speciosin A/ (1R,5S,6R)1-(3-Buten-1-yn-1-yl)-5hydroxy-7-

oxabicyclo[4.1.0]hept-3en-2-one

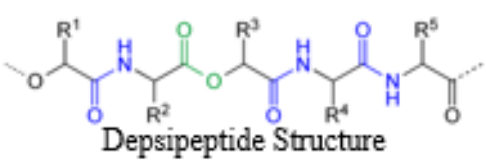<smiles>CC(C)C1C(=O)OC(C(C)C)N(C)C1=O</smiles>

3,6-Diisopropyl-4-methyl-2,5-morpholinedione<smiles>CC(C)C1OC(=O)C(C(C)C)N(C)C1=O</smiles>

3,6-Diisopropyl-4-methyl-2,5-morpholinedione 